\title{
Degree of Reclamation of a Saline-Sodic Soil in Lajas Valley, Puerto Rico ${ }^{1}$
}

\author{
G. Acevedo Ramos, J. A. Bonnet, and J. Ortiz Vélez ${ }^{2}$
}

\section{INTRODUCTION}

In Puerto Rico there is urgent need to increase the area of productive cultivated land in order to produce more food for the $21 / 3$ million inhabitants and so help to improve the general welfare of the Island. The Lajas Valley in southwestern Puerto Rico constitutes one of the last frontiers for extending cultivated land in the Island. A drainage-irrigation reclamation project had advanced to the point that there are already large tracts under intensive cultivation in the Valley. However, the arid lowlands of Lajas Valley are to some extent affected by sporadic extensive patches with salinity problems.

In 1945, the Soils Department of the Agricultural Experiment Station of the University of Puerto Rico initiated extensive studies of the soil problems of Lajas Valley. These studies included morphological, physical, chemical, and mineralogical characterization; irrigation-water quality; and measurements of infiltration rates and leaching tests under field conditions ( 1 , 2). ${ }^{3}$ A more detailed salinity survey of the Valley was conducted from July 1954 to March 1955 , comprising a total area of 24,544 acres $(3,4)$. The proportions of normal, saline-sodic, nonsaline-sodic, and saline soils of the area studied, as reported by Bonnet and Brenes, are shown in table $1(5)$. Since the survey of the salinity status of the soils indicated that the salinesodic soils presented the major problems, and that such soil increases in area with depth, it was considered advisable to select a saline-sodic soil for experimental work on reclamation procedures.

This paper reports the preliminary results obtained in the attempt to reclaim with chemicals and organic amendments such a saline-sodic soil.

\footnotetext{
1 Joint contribution from the Department of Soils and the Lajas and Gurabo Substations.

${ }^{2}$ Research Assistant in Soils, Soil Chemist and Head Department of Soils, and Assistant Drainage Scientist, respectively, Agricultural Experiment Station, University of Puerto Rico, Río Piedras, P.R. Appreciation is expressed to E. J. Brenes, Assistant Soil Scientist, for his help in planning and during the initial stages of the work, and to Dr. M. A. Lugo-López, Assistant Director in Charge of the Gurabo Substation, for helpful suggestions in the preparation of the manuscript. The authors also wish to express their appreciation to R. Pérez Escolar, Assistant Soil Scientist, F. Díaz, Research Assistant in Irrigation Engineering, and L. S. Willardson, former Irrigation Engineer of Lajas Substation, for their help in soil sampling, irrigation of the experiment, and providing adequate drainage for it, respectively.

${ }^{3}$ Italic numbers in parentheses refer to Literature Cited, p. 170-1.
} 


\section{MATERIALS AND METHODS}

The reclamation experiment was started on a saline-sodic soil in the northeastern part of Lajas Valley. The soil, classified as Fe clay, is a heavy dark-gray, plastic clay grumusol with numerous lime concretions. Gypsum crystals are found at lower depths. Montmorillonite is the dominant clay mineral. Hydraulic conductivity is slow, especially in the lower subsoil and, in general, the physical properties are rather undesirable $(7,9)$.

The area studied was divided into 24 plots 15 by 20 feet in size each. Earth borders were erected to form individual basins. Because subsurface drainage is essential for the reclamation of saline-sodic soils with low permeability, tile drains were installed at a 6-foot depth and a 60-foot spacing. The tiles were packed in gravel and the effluent discharged into an open drain connected to the main drainage canal of the Lajas Valley. At the

TABLe 1.-Percentages of normal, saline-sodic, nonsaline-sodic, and saline soils, according to depth of sampling, in 24,544 acres surveyed and sampled in the

\begin{tabular}{c|c|c|c|c}
\multicolumn{5}{c}{ Lajas Valley } \\
$\begin{array}{c}\text { Depth } \\
\text { (inches) }\end{array}$ & Normal & Saline-sodic & Nonsaline-sodic & Saline \\
\hline $0-8$ & 86 & 8 & 1 & 5 \\
$8-24$ & 64 & 20 & 8 & 8 \\
$24-48$ & 34 & 48 & 11 & 8 \\
$48-72$ & 23 & 58 & 11 & 8 \\
\hline
\end{tabular}

${ }^{1}$ Reported by Bonnet and Brenes (5).

beginning of the experiment a heavy rainfall caused considerable damage to the experimental site; the earth borders were washed out and the ditches destroyed. The earth borders were than replaced by aluminum sheets painted black to protect them from salt corrosion (fig. 1).

The treatments, replicated four times in a partly balanced incompleteblock design, were as follows:

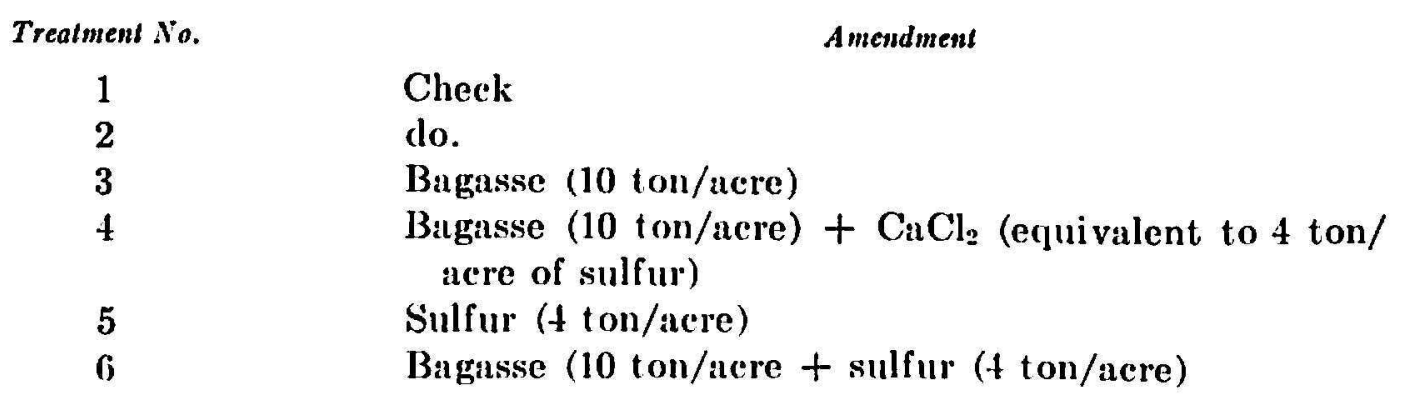

The bagasse and the sulfur were broadeast on the surface soil and then incorporated by means of a rotavator. All plots were flooded with fresh 
water at rarious time intervals using a portable gasoline-driven centrifugal pump. All treatments, except one check group left bare, were to be planted with a suitable crop at a convenient time after reclamation.

Soil samples were taken periodically at the following depths: $0-8,8-16$, 16-24, 24-36, and 36-48 inches, after applying, respectively, 34, 50, and

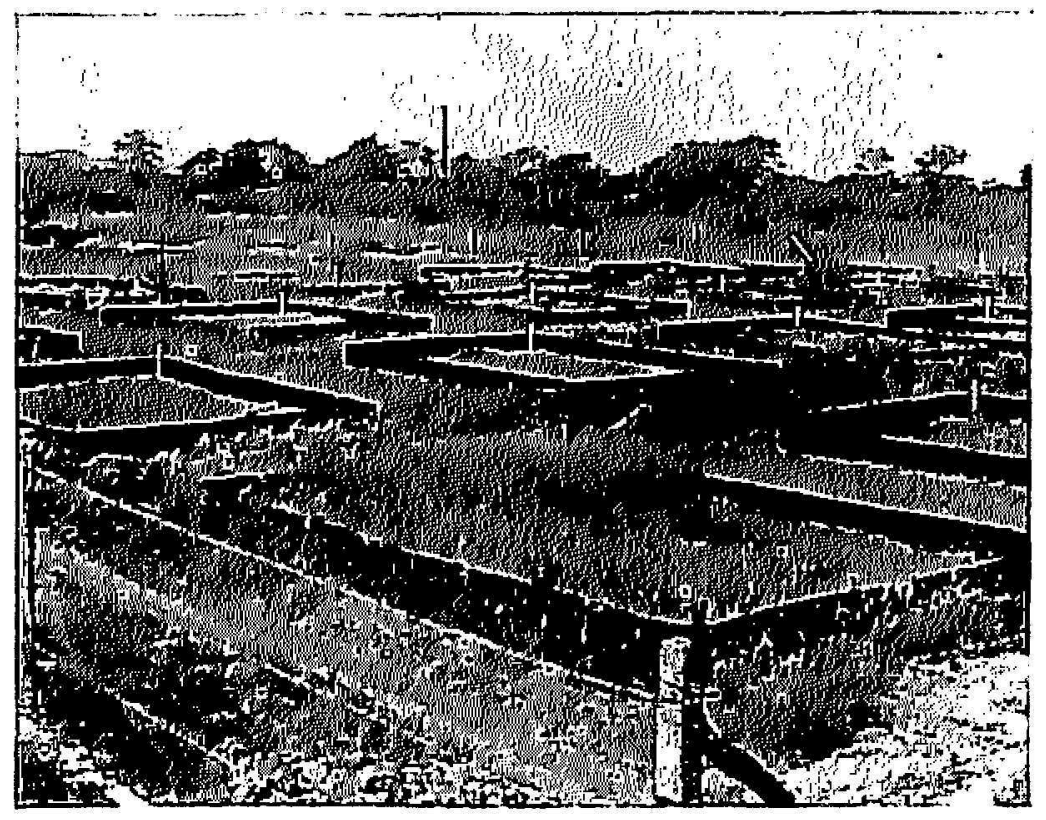

Fig. 1.-View of experimental plots used for the experiment on reclamation of a saline-sodic soil in Lajas Valley, P.R.

TABLE 2.-Percentages of the all-treatments mean salt content of the saline-sodic soil removed in relation to depth after increased applications of water

\begin{tabular}{c|c|c|c}
\hline \multirow{2}{*}{$\begin{array}{c}\text { Depth } \\
\text { (inches) }\end{array}$} & \multicolumn{2}{|c}{ Salt removed after the application of- } \\
\cline { 2 - 4 } & 34 inches of water & 50 inches of water & 94 inches of water \\
\hline $0-8$ & 65.6 & 73.9 & 76.5 \\
$8-16$ & 60.8 & 70.9 & 71.7 \\
$16-24$ & 39.9 & 59.0 & 54.5 \\
$24-36$ & 38.1 & 53.5 & 41.2 \\
$36-48$ & 28.9 & 43.1 & 22.2 \\
\hline
\end{tabular}

94 inches of water of irrigation and rainfall. The samples were air-dried and ground in a corn mill.

$\therefore$ A saturated soil paste was then prepared using $100 \mathrm{gm}$. of air-dry soil to obtain a water-saturation extract following the procedure outlined in Agricultural Handbook (i0 (8). The electrical conductivity (EC) of the soil extract expressed in millimhos per centimeter at $25^{\circ} \mathrm{C}$ and the exchangeable sodium percentage (ESI) of the soil were used as indies of the reclama- 
tion effectiveness. The EC value multiplied by 10 expressed the total soluble-salt content in terms of milliequivalents per liter. The ESP value was obtained from the monogram on page 103 of the above-mentioned Handbook.

TABLE 3.-Mean exchangeable sodium percentages for all treatments in the saline-sodic soil removed after increased application of water

\begin{tabular}{c|c|c|c}
\hline $\begin{array}{c}\text { Depth } \\
\text { (inches) }\end{array}$ & \multicolumn{2}{|c}{ Exchangeable sodium percentage removed after the application of- } \\
\cline { 2 - 3 } & 34 inches of water & 50 inches of water & 94 inches of water \\
\hline $0-8$ & 39 & 46 & 44 \\
$8-16$ & 15 & 27 & 19 \\
$16-24$ & 12 & 22 & 18 \\
$24-36$ & 9 & 18 & 8 \\
$36-48$ & 1 & 10 & 3 \\
\hline
\end{tabular}

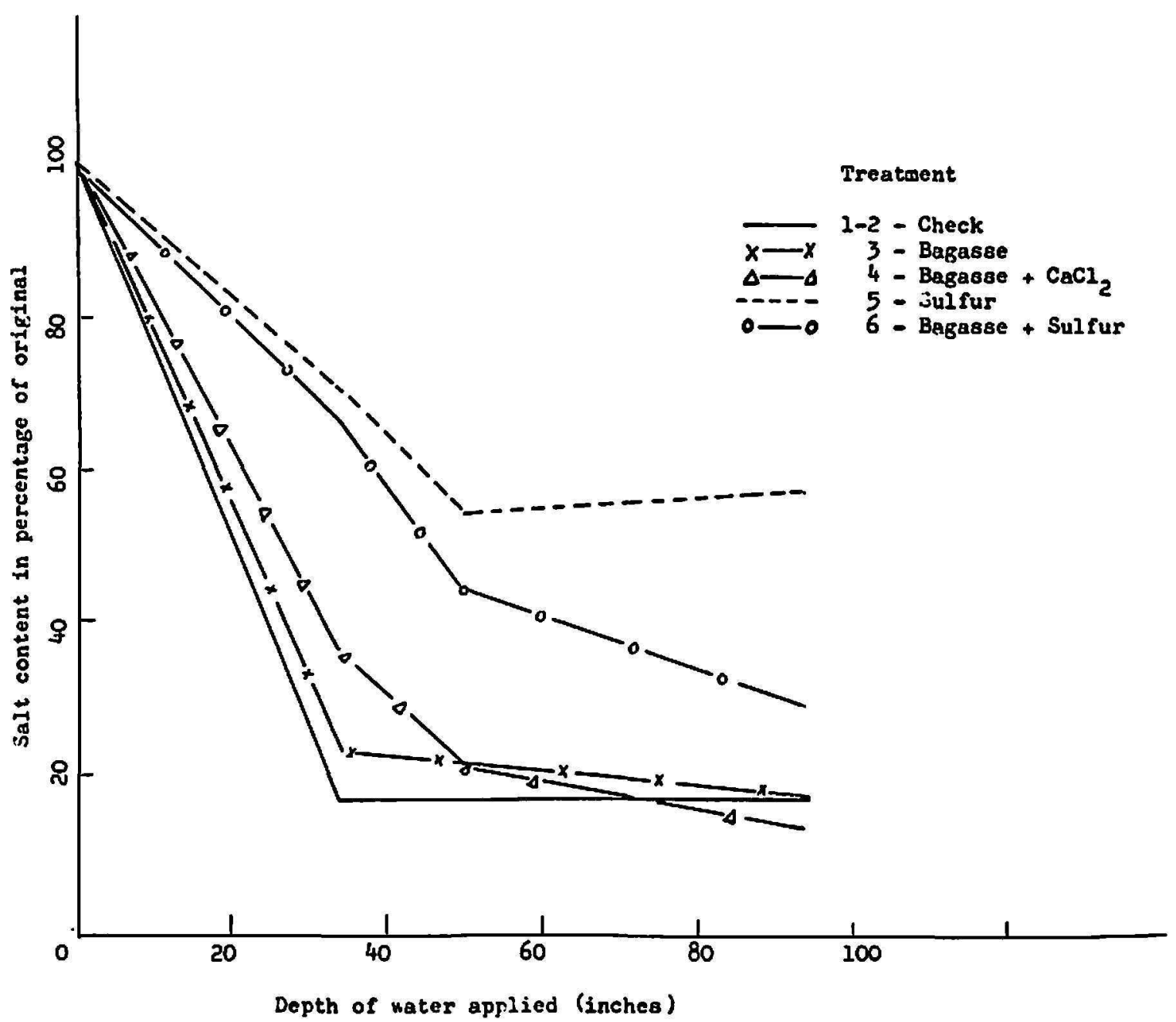

FIG. 2.-Salts removed at a soil depth of 0-8 inches with increasing water applications from different treatments. 


\section{RESULTS AND DISCUSSION}

Tables 2 and 3 present data on the removal of mean soluble salts and of mean ESP corresponding to the treatments given the saline-sodic soil under reclamation in Lajas Valley. The soluble-salt content of the soil in all treatments was reduced by the water applied (figs. 2 to 6 ). However in the

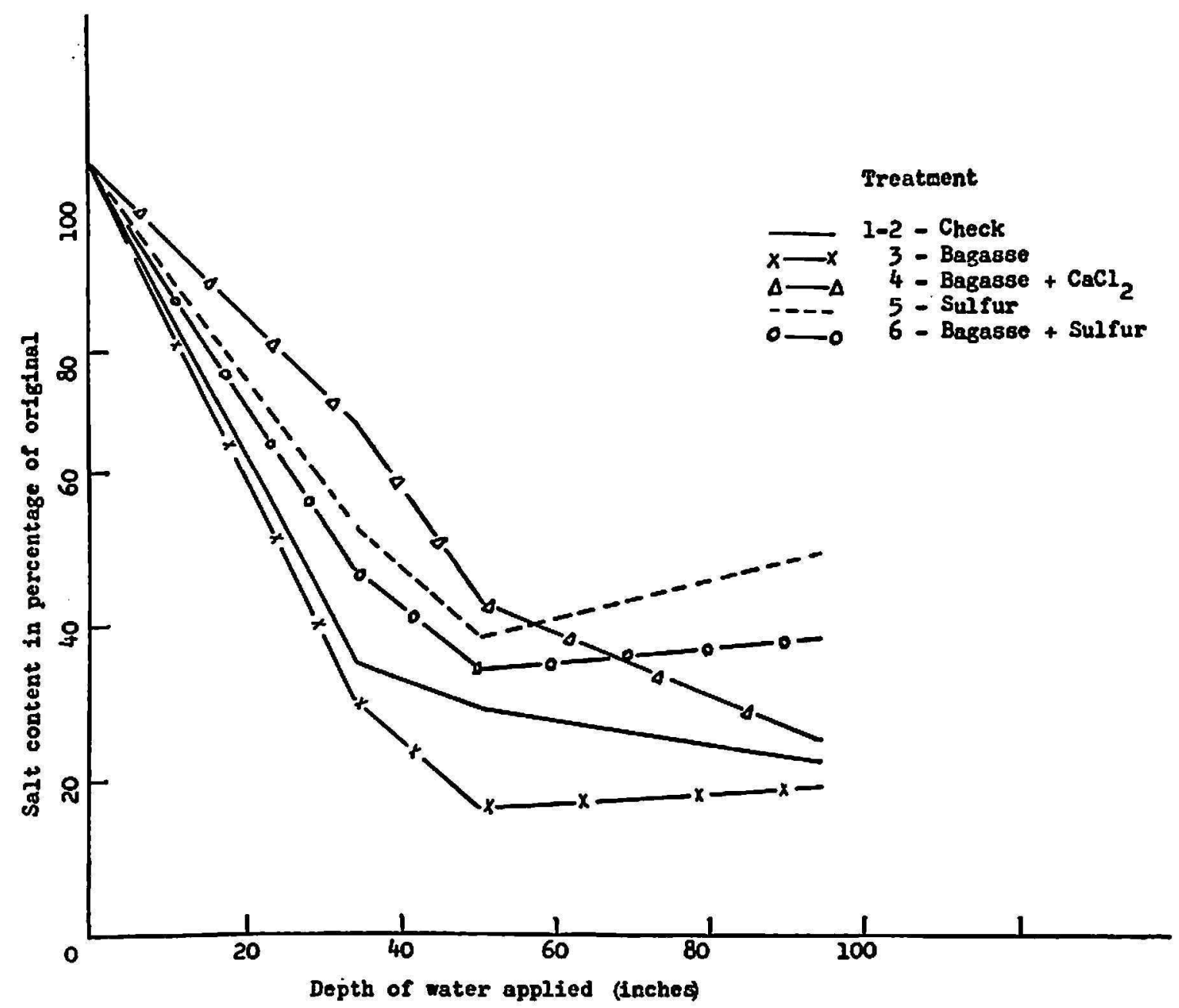

FIG. 3.-Salts removed at a soil depth of 8-16 inches with increasing water applications from different treatments.

check, 1-2, and under treatments 3 and 4, the soluble salts in the soil were reduced more rapidly in the 0-8-inch layer than under treatments 5 and 6 (figs. 2 to 6). The leaching of salts was caused by the water since no chemical amendments were added to the check plots nor to those that received bagasse. In treatment 4 , which received bagasse and calcium chloride, the salts were lowered rapidly because of the combined effect of calcium chloride, by its flocculating action, and of bagasse by its favorable influence on the soil physical properties which induced a more rapid infiltration and 
movement of water through the clay profile. In the sulfur treatment the sulfur apparently mobilized some of the soil insoluble calcium carbonate (6) into soluble form and, to some extent, maintained the soil extract EC at higher values. In the plots that received bagasse and sulfur the considerable decrease in salt content could probably be explained by the favorable effect of the bagasse on the physical condition of the soil.

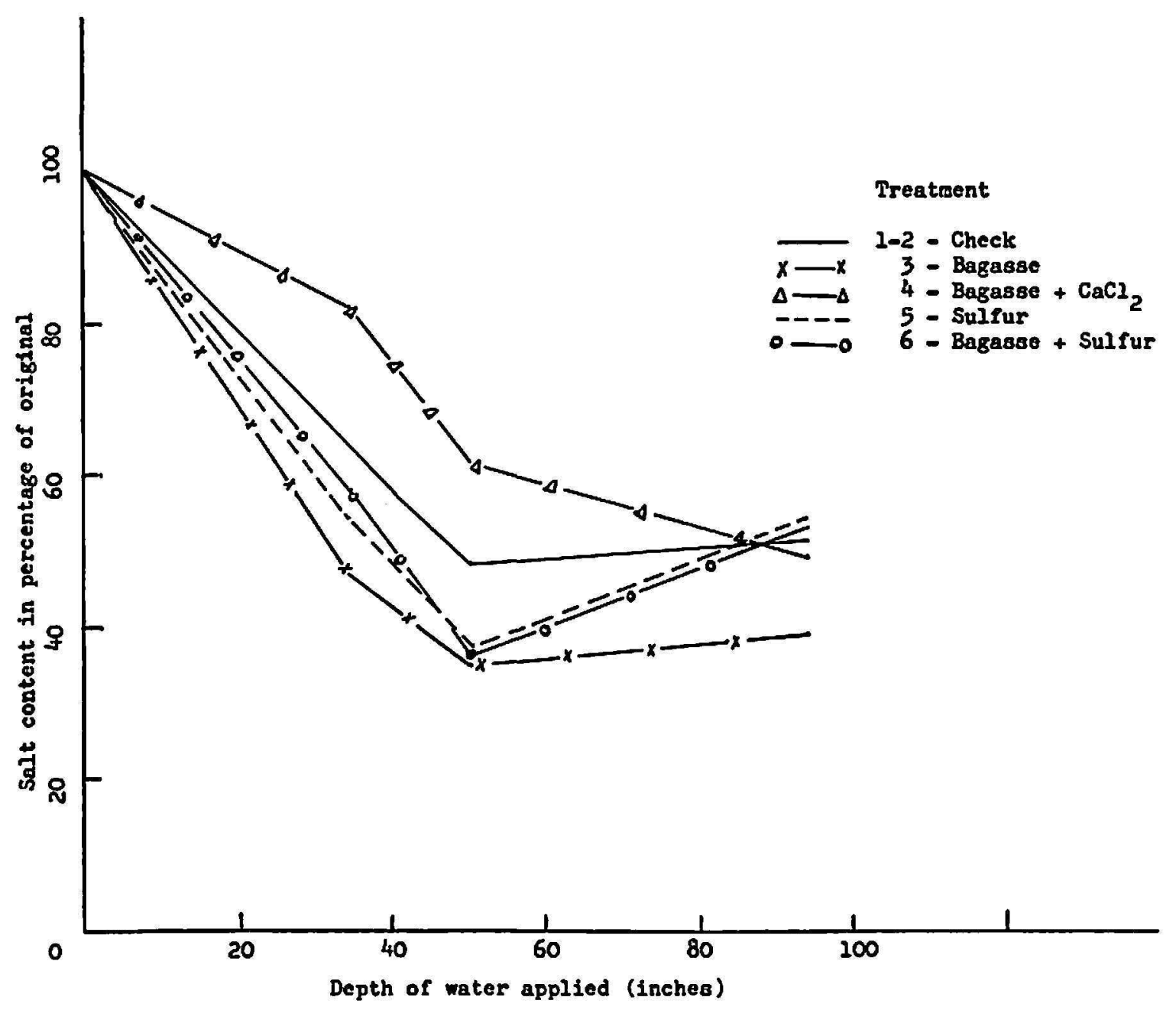

FIG. 4.-Salts removed at a soil depth of 16-24 inches with increasing water applications from different treatments.

In all cases the reduction of the salt content was more effective in the upper layers of the soil, as shown in figures 2 to 6 and in table 2. At least the water added was more effective in leaching the surface-soil layer since the salt removed from the top may have accumulated at the lower soil levels. The low permeability of the subsoil also prevented the lower layers from receiving an effective amount of water for the removal of soluble salts. It is of importance to know the effect of continued additions of water on the salt movement at the soil profile's lower depths. 
Since the water applied considerably reduced the soluble salts in the saline-sodic soil, especially at the beginning of the experiment and from the upper layers of the soil, the water itself can be considered as an index for properly timing the application of amendments. These should be applied only after a given quantity of water has moved through the soil profile as long as the hydraulic conductivity rate permits it. Field observations

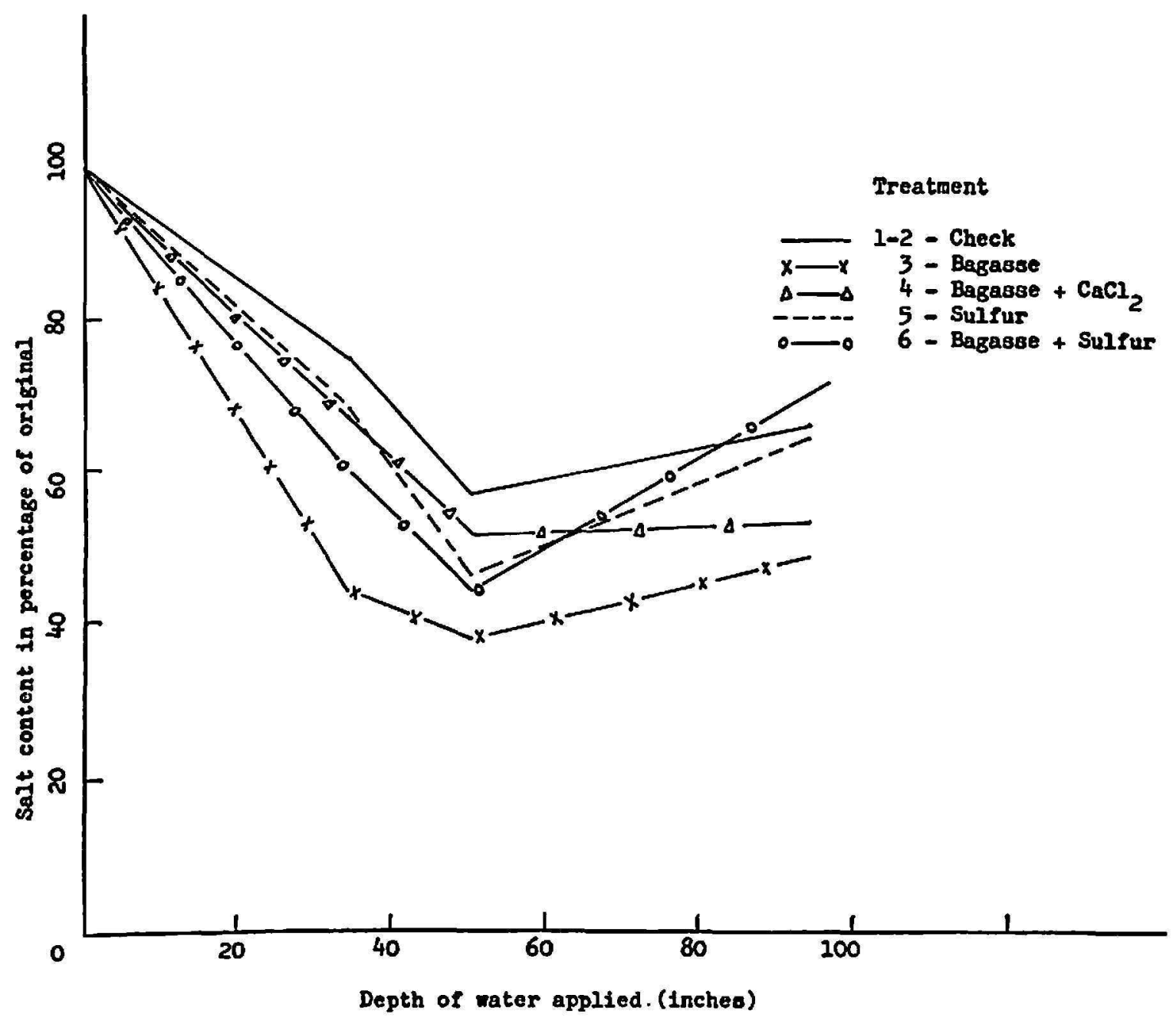

Fra. 5.-Salts removed at a soil depth of 24-36 inches with increasing water applications from different treatments.

and physical analyses demonstrated that the movement of water through this soil was slow, mainly because of its high clay content, its high exchangeable sodium, and the presence of high-swelling clay minerals, predominantly montmorillonite.

It must be clearly understood that the reclamation of a saline-sodic soil is not complete unless the exchangeable sodium of the soil colloids is reduced to a level not detrimental to plant growth and development. The harmful effect of the sodium ion on plant growth and its adverse effect on 
the physical condition of the soil, dispersing and puddling it and reducing soil aereation, have been long recognized (8). Data on the removal of exchangeable sodium in the soil are presented graphically in figures 7 to 11 . A tendency to lower exchangeable sodium with leaching is evident, especially on those plots receiving bagasse-calcium chloride, sulfur, and bagasse-

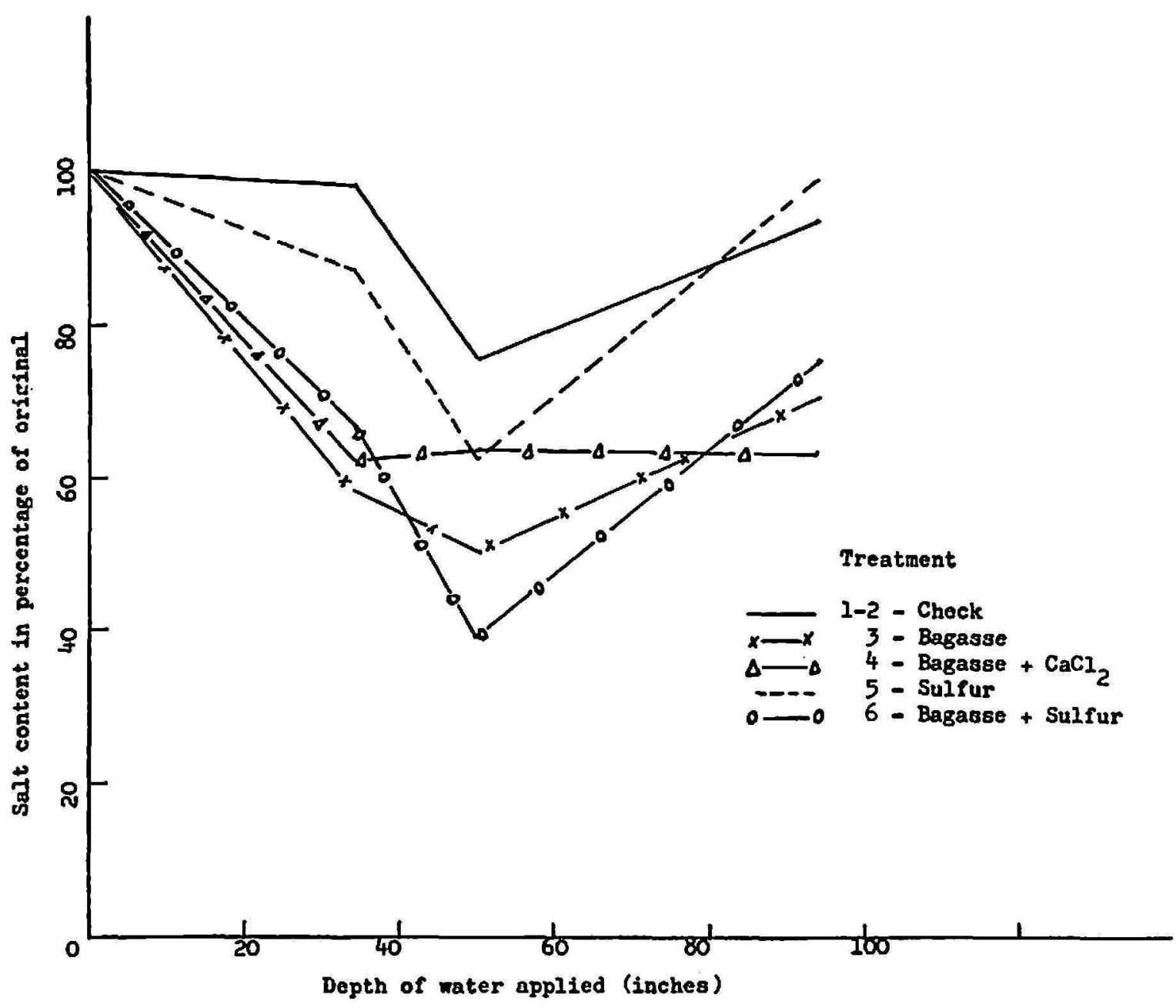

Fig. 6.-Salts removed at a soil depth of $36-48$ inches with increasing water applications from different treatments.

sulfur. This was more pronounced at the uppermost layers as shown in figures 7, 8, and 9 .

In contrast to the data previously discussed on the removal of soluble salts, neither water alone (check plots) nor the bagasse effectively lowered the exchangeable sodium to the desired levels. A chemical amendment such as sulfur, gypsum, or calcium chloride, is further needed for the complete reclamation of a saline-sodic soil. In figure 11 an accumulation of exchangeable sodium after the application of 34 inches of water is shown, indicating the lixiviation of sodium from the upper soil layers. The ESP 
decreased with depth, as is generally shown in figures 7 to 11 and in table 3. The mean values obtained for the EC and the ESP of the soil before and after leaching with water in all treatments are presented in table 4.

Sulfur must undergo oxidation mainly by specific soil bacteria to aid in the reclamation of a saline-sodic soil. After oxidation to sulfuric acid it is

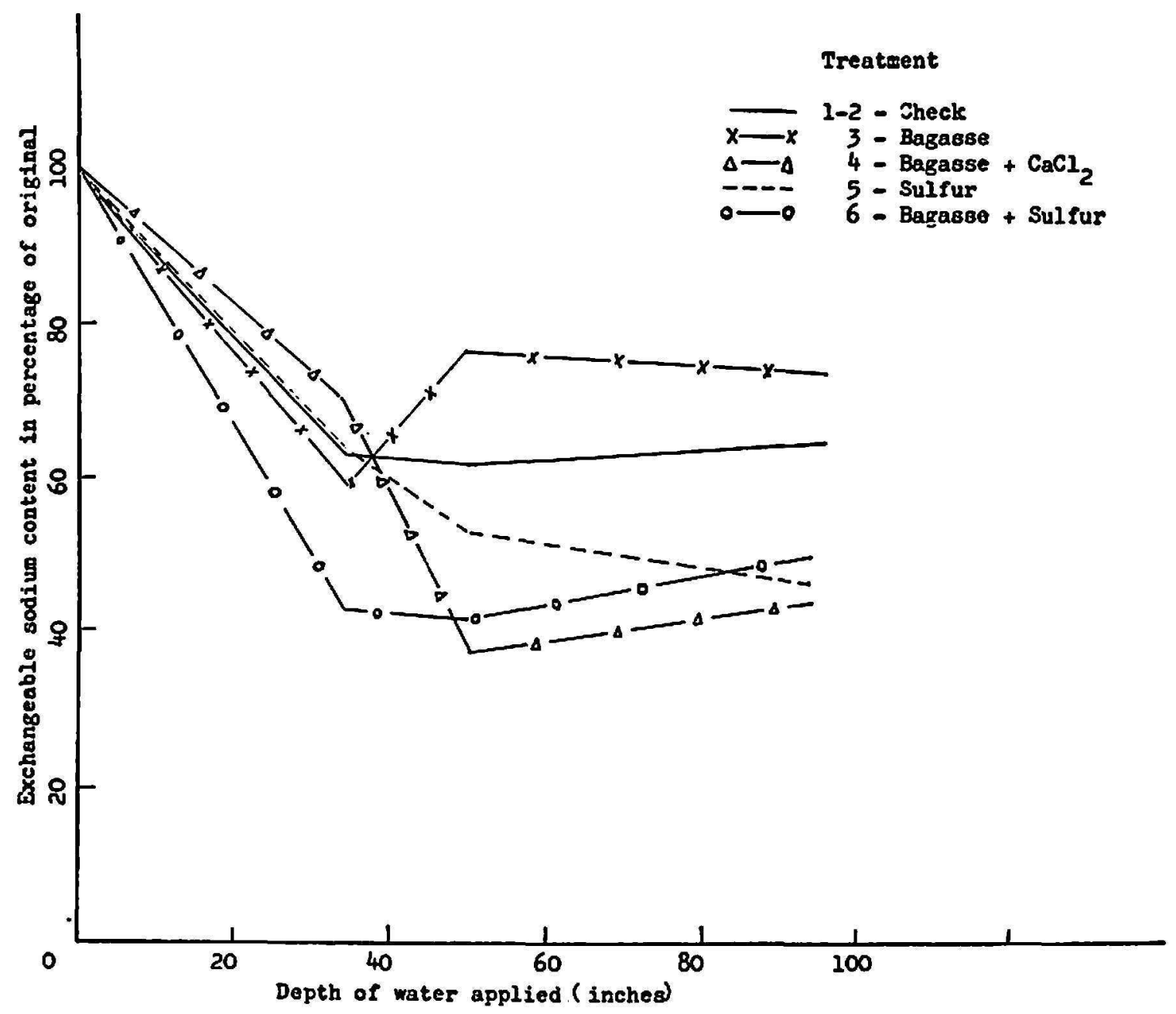

FIG. 7.-Exchangeable sodium percentage removed at a soil depth of $0-8$ inches with increasing water applications under different treatments.

effective in the removal of exchangeable sodium. The bagasse provides favorable aeration conditions for the oxidation of sulfur. The sulfur treatment markedly reduced the exchangeable sodium in the surface layer, but the bagasse-sulfur treatment worked as well at the surface and lowered the ESP deeper in the soil profile as shown in figures 8 and 9.

In general, it can be concluded that, for the reclamation of a saline-sodic soil, there is need to remove both soluble salts and exchangeable sodium from it. Good soil drainage must be maintained. The experimental data so 
far demonstrate that there is a tendency to lower soluble salts and exchangeable sodium in the soil after the application of 94 inches of water. This tendency is more pronounced at the surface. Additional data under process of collection at present should provide a more accurate evaluation

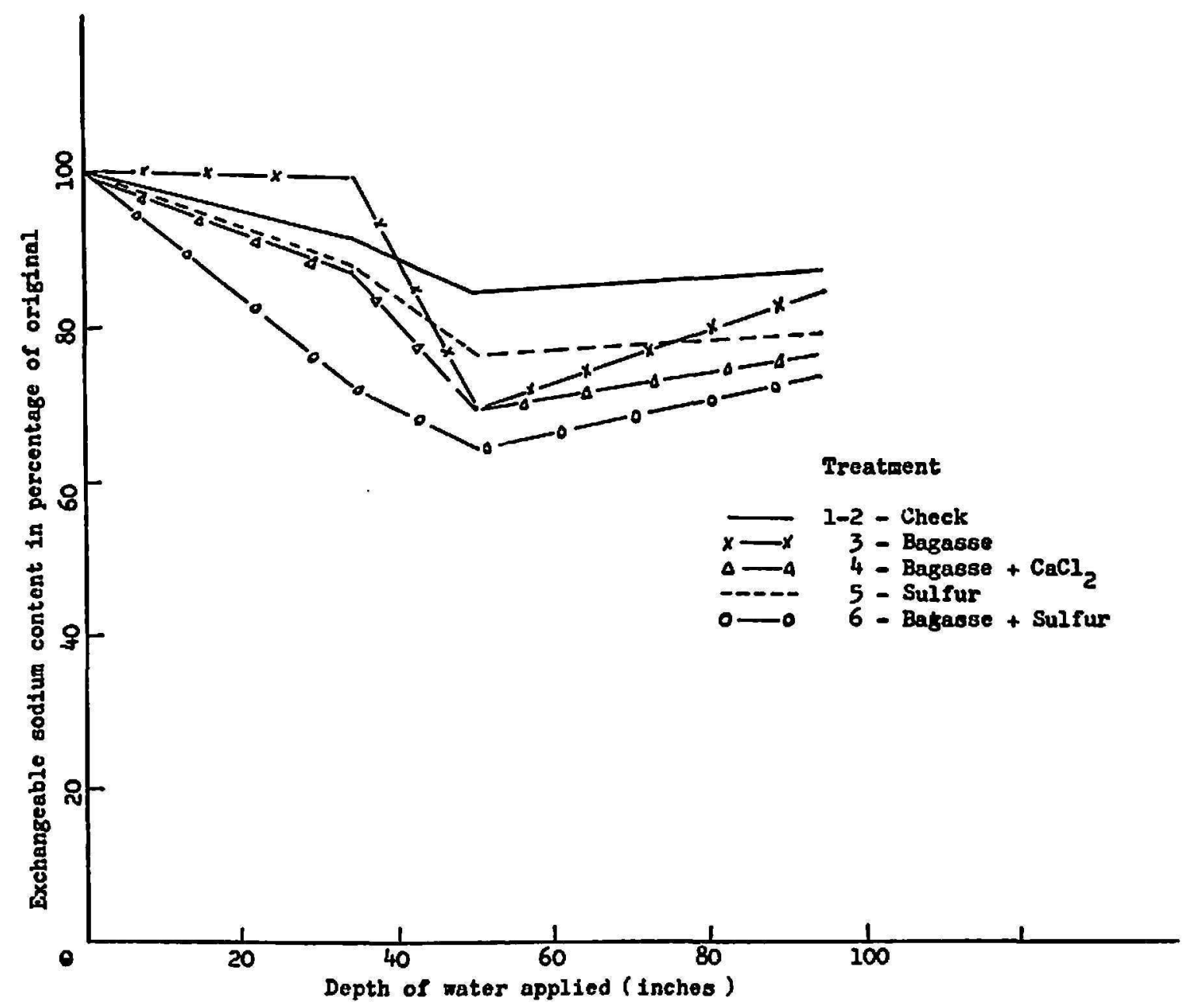

FIG. 8.-Exchangeable sodium percentage removed at a soil depth of 8-16 inches with increasing water applications under different treatments.

of the factors involved in the reclamation of saline-sodic soils under conditions similar to those that prevail in the Lajas Valley experimental set-up.

\section{SUMMARY}

In Lajas Valley, in southwestern Puerto Rico, there is a rather large portion of saline-sodic soils. These require reclamation if normal plant growth is to be sustained by them. A field experiment was initiated including six treatments: Two identical checks, and treatments with bagasse, bagasse-calcium chloride, sulfur, and bagasse-sulfur. The experimental plots were flooded periodically with fresh water. Soil samples were collected 
at different depths and analyzed to study the removal of soluble salts and exchangeable sodium. Data reported include values for electrical conductivity (EC) of soil extracts and exchangeable sodium percentage (ESP) in the soil.

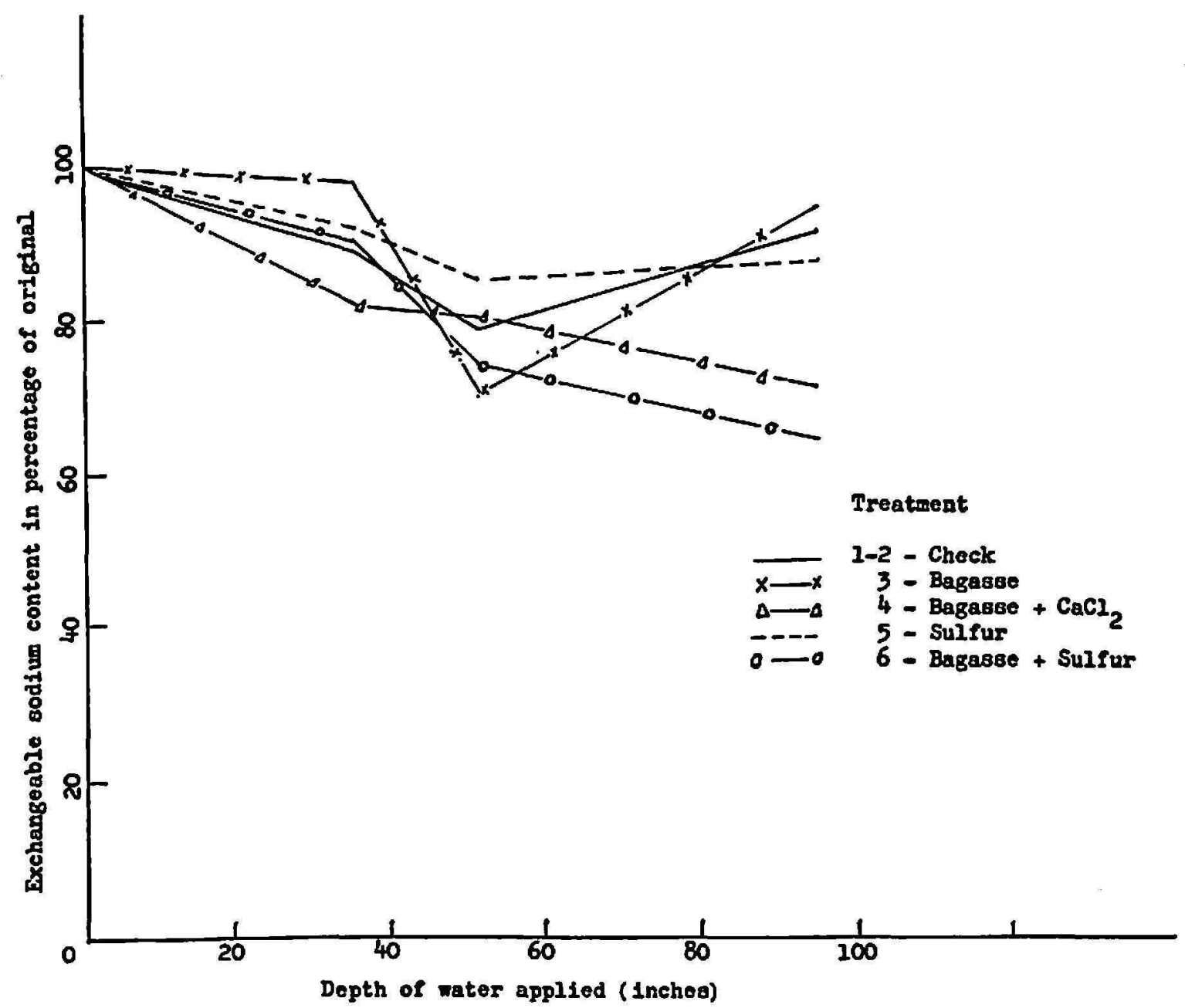

Fra. 9.-Exchangeable sodium percentage removed at a soil depth of 16-24 inches with increasing water applications under different treatments.

Results so far obtained in the reclamation experiment may be summarized as follows:

1, Application of 94 inches of water up to the maximum used to date tends to lower the soluble salts and the soil exchangeable sodium, regardless of treatment differentials.

2 , The removal of the soluble salts and the reduction in exchangeable sodium were less effective in the lower layers of the soil.

3 , Sulfur and calcium chloride tend to be more effective in lowering the exchangeable sodium percentage in the colloids of the surface layer of the soil. 
4, There is need of a chemical amendment in addition to water and drainage if the exchangeable sodium percentage in the soil is to be lowered effectively.

\section{RESUMEN}

En el Valle de Lajas, en el suroeste de Puerto Rico, hay un gran número de suelos salino-sódicos que requieren ser restaurados para que puedan

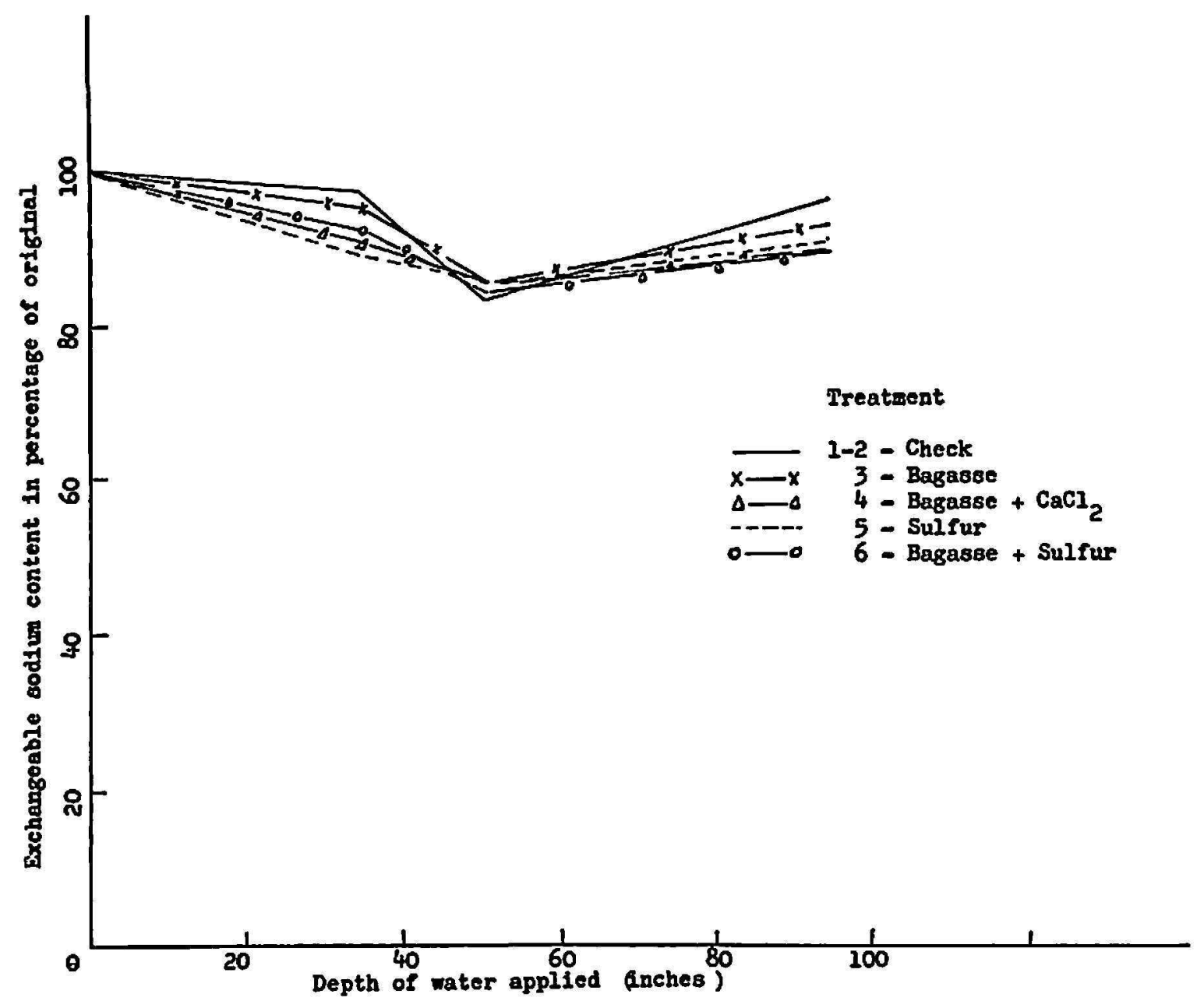

FIG. 10.-Exchangeable sodium percentage removed at a soil depth of 24-36 inches with increasing water applications under different treatments.

producir cosechas adecuadas. Para obtener la información básica necesaria se ha instalado un experimento de campo en uno de estos suelos. El experimento incluye seis tipos de tratamientos de las parcelas experimentales, a saber: Aplicación de bagazo, de bagazo y cloruro de calcio, de azufre, de bagazo y azufre y parcelas testigos que solo recibieron lavados con agua al igual que todas las demás parcelas. Se aplicó agua de riego de buena calidad periódicamente. Se tomaron muestras de suelo y se analizaron para estudiar el movimiento de las sales solubles y del sodio intercambiable a distintas profundidades. 
Los datos aquí informados incluyen valores de conductividad eléctrica de los extractos de suelo y porcentaje de sodio intercambiable en el suelo. Los resultados obtenidos hasta ahora en la restauración de un suelo salinosódico del Valle de Lajas bajo estudio pueden resumirse en la siguiente forma:

1. La aplicación de 94 pulgadas de agua de riego claramente tiende a

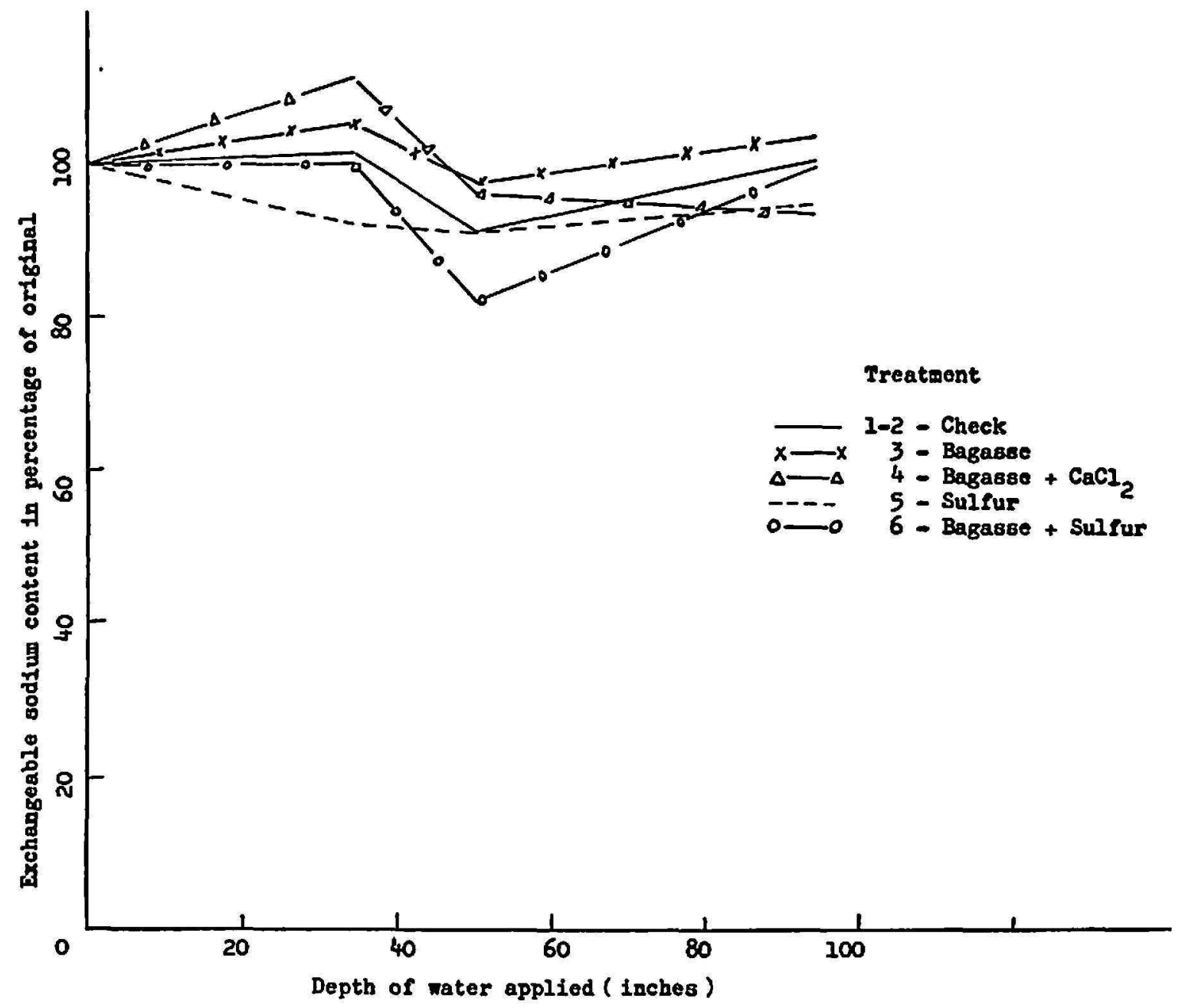

Frg. 11.-Exchangeable sodium percentage removed at a soil depth of 36-48 inches with increasing water applications under different treatments.

bajar las sales y el sodio intercambiable, sin importar las diferencias en tratamientos.

2. La remoción de sales solubles y de sodio intercambiable en el suelo es más eficaz en las capas superficiales.

3. Los tratamientos con azufre y cloruro de calcio parecen ser los más eficaces para bajar el porcentaje de sodio intercambiable en las capas superiores del suelo.

4. Se notó la necesidad de una enmienda química, además de agua y desagüe, para bajar la proporción de sodio intercambiable en el suelo. 
TABLE 4.- Mean electrical conductivity $(E C)$ and exchangeable sodium percentage (ESP) for all treatments in the saline-sodic soil in relation to depth after increased application of water

\begin{tabular}{|c|c|c|c|c|c|c|c|c|c|}
\hline \multirow{3}{*}{$\begin{array}{l}\text { Treatment } \\
\text { No. }\end{array}$} & \multirow{3}{*}{ Depth } & \multicolumn{8}{|c|}{$\begin{array}{l}\text { Electrical conductivity and exchangeable sodium percentage of the original } \\
\text { soil and after the application of - }\end{array}$} \\
\hline & & \multicolumn{2}{|c|}{0 (original soil) } & \multicolumn{2}{|c|}{34 inches of water } & \multicolumn{2}{|c|}{50 inches of water } & \multicolumn{2}{|c|}{94 inches of water } \\
\hline & & ECI & ESP2 & $\mathbf{E C}$ & ESP & EC & ESP & $\mathrm{EC}$ & ESP \\
\hline & Inches & Mlmhos/cm. & Percent & Almhos $/ \mathrm{cm}$ & Percent & $1 /$ mlios $/ \mathrm{cm}$ & Percent & armitos $/ \mathrm{cm}$ & Percent \\
\hline $1-2$ & $\begin{array}{c}0-8 \\
8-16 \\
16-24 \\
24-36 \\
36-48\end{array}$ & $\begin{array}{l}16.5 \\
23.9 \\
31.3 \\
31.8 \\
20.0\end{array}$ & \begin{tabular}{|l|}
38 \\
42 \\
40 \\
41 \\
42
\end{tabular} & $\begin{array}{r}2.7 \\
7.5 \\
21.6 \\
22.6 \\
23.8\end{array}$ & $\begin{array}{l}25 \\
37 \\
35 \\
38 \\
42\end{array}$ & $\begin{array}{r}2.0 \\
6.6 \\
14.3 \\
17.1 \\
18.0\end{array}$ & $\begin{array}{l}22 \\
35 \\
33 \\
33 \\
38\end{array}$ & $\begin{array}{r}2.5 \\
4.9 \\
15.0 \\
20.0 \\
22.7\end{array}$ & \begin{tabular}{|l|}
24 \\
35 \\
36 \\
39 \\
42
\end{tabular} \\
\hline 3 & $\begin{array}{c}0-8 \\
8-16 \\
16-24 \\
24-36 \\
36-48\end{array}$ & \begin{tabular}{l|l|}
15.8 & \\
27.3 \\
31.3 \\
38.0 \\
32.3
\end{tabular} & $\begin{array}{l}33 \\
38 \\
38 \\
42 \\
42\end{array}$ & $\begin{array}{r}2.3 \\
5.9 \\
13.4 \\
15.7 \\
17.0\end{array}$ & $\begin{array}{l}22 \\
36 \\
37 \\
40 \\
44\end{array}$ & $\begin{array}{r}2.3 \\
4.6 \\
10.1 \\
14.0 \\
14.4\end{array}$ & $\begin{array}{l}24 \\
25 \\
27 \\
36 \\
39\end{array}$ & $\begin{array}{r}2.1 \\
3.8 \\
11.1 \\
18.0 \\
21.0\end{array}$ & $\begin{array}{l}23 \\
30 \\
36 \\
39 \\
43\end{array}$ \\
\hline 4 & $\begin{array}{c}0-8 \\
8-16 \\
16-24 \\
24-36 \\
36-48\end{array}$ & $\begin{array}{l}14.3 \\
20.3 \\
26.3 \\
28.8 \\
27.8\end{array}$ & $\begin{array}{l}37 \\
37 \\
37 \\
41 \\
43\end{array}$ & $\begin{array}{r}4.6 \\
11.0 \\
18.6 \\
17.7 \\
16.7\end{array}$ & $\begin{array}{l}25 \\
32 \\
30 \\
37 \\
47\end{array}$ & \begin{tabular}{r|}
2.8 \\
7.0 \\
13.3 \\
13.6 \\
15.9
\end{tabular} & $\begin{array}{l}14 \\
25 \\
29 \\
34 \\
40\end{array}$ & $\begin{array}{r}1.9 \\
4.6 \\
11.0 \\
13.7 \\
15.6\end{array}$ & $\begin{array}{l}16 \\
28 \\
26 \\
36 \\
39\end{array}$ \\
\hline 5 & $\begin{array}{c}0-8 \\
8-16 \\
16-24 \\
24-36 \\
36-48\end{array}$ & $\begin{array}{l}14.6 \\
21.0 \\
26.5 \\
26.8 \\
22.8\end{array}$ & $\begin{array}{l}36 \\
38 \\
39 \\
43 \\
44\end{array}$ & $\begin{array}{r}9.7 \\
10.1 \\
13.2 \\
17.7 \\
19.4\end{array}$ & $\begin{array}{l}22 \\
32 \\
35 \\
38 \\
40\end{array}$ & $\begin{array}{r}7.3 \\
7.3 \\
9.5 \\
11.9 \\
13.7\end{array}$ & $\begin{array}{l}19 \\
28 \\
32 \\
36 \\
39\end{array}$ & \begin{tabular}{r|}
8.1 \\
9.6 \\
13.4 \\
16.7 \\
22.2
\end{tabular} & $\begin{array}{l}17 \\
29 \\
34 \\
39 \\
41\end{array}$ \\
\hline 6 & $\begin{array}{c}0-8 \\
8-16 \\
16-24 \\
24-36 \\
36-48\end{array}$ & $\begin{array}{l}12.8 \\
18.9 \\
22.5 \\
23.9 \\
26.8\end{array}$ & $\begin{array}{l}34 \\
41 \\
41 \\
42 \\
42\end{array}$ & $\begin{array}{r}7.9 \\
9.0 \\
13.2 \\
14.3 \\
16.6\end{array}$ & $\begin{array}{l}14 \\
29 \\
36 \\
38 \\
42\end{array}$ & $\begin{array}{r}5.4 \\
6.3 \\
8.1 \\
10.3 \\
10.6\end{array}$ & $\begin{array}{l}14 \\
26 \\
30 \\
34 \\
35\end{array}$ & $\begin{array}{r}3.8 \\
7.0 \\
11.9 \\
16.5 \\
19.2\end{array}$ & $\begin{array}{l}16 \\
29 \\
26 \\
37 \\
42\end{array}$ \\
\hline
\end{tabular}

${ }^{1}$ Values for EC below 4, inclusive, indicate normality as to salt content.

2 Values for ESP below 15, inclusive, indicate normality as to exchangeable sodium content.

\section{LITERATURE CITED}

1. Bonnet, J. A., Tirado-Sulsona, P., and Lugo- López, M. A., Attempt to reclaim with chemicals a salty clay in Puerto Rico, J. Agr. Univ. P.R. 33(2) 75-84, 1949.

2. Bonnet, J. A., and Tirado-Sulsona, P., Soil Studies in Lajas Valley, Univ. P.R. Agr. Exp. Sta. Bul. 86, 3-64, 1950. 
3. Bonnet, J. A., and Brenes, E. J., Salinity problems on heavy calcareous impermeable clays of southwestern arid Puerto Rico, Sixiéme Congrés de la Science du Sol. Paris 515-19, 1956.

4. - Salinity status of Lajas Valley soils, J. Agr. Univ. P.R. 41(1) 25-34, 1957.

5. - Detailed Salinity Survey of Lajas Valley, Univ. P.R. Agr. Exp. Sta. Bul. 141, 5-114, 1958.

6. Kelley, W. P., Alkali Soils, Their Formation, Properties, and Reclamation, Reinhold Pub. Corp., New York, N.Y., 160, 1951.

7. Lugo-López, M. A., Pérez-Escolar, R., Acevedo, G., and Juárez, Jr., J., Nature and Properties of Major Soils of Lajas Valley, Univ. P.R. Agr. Exp. Sta. Bul. 144, 1959.

8. Richards, L. A., Allison, L. E., Brown, J. W., Hayward, H. E., Berstein, L., Fireman, M., Pearson, G. A., Wilcox, L. V., Bower, C. A., Hatcher, J. T., and Reeve, R. C., U.S. Salinity Laboratory Staff, Agr. Handbook No. 60, USDA 160 pp., 1954.

9. Willardson, L. S., Lajas Valley Drainage Problems, Univ. P.R. Agr. Exp. Sta. Bul. 143, 5-64, 1958. 